\title{
Social Origins of Dictatorships: Elite Networks and Political Transitions in Haiti
}

\author{
SURESH NAIDU Columbia University
}

\section{JAMES A. ROBINSON University of Chicago}

\section{LAUREN E. YOUNG University of California, Davis}

\begin{abstract}
7 xisting theories of democratic reversals emphasize that elites mount actions like coups when $A$ democracy is particularly threatening to their interests. However, existing theory has been largely silent on the role of elite social networks, which interact with economic incentives and may facilitate antidemocratic collective action. We develop a model where coups generate rents for elites and show that the effort an elite puts into a coup is increasing in their network centrality. We empirically explore the model using an original dataset of Haitian elite networks that we linked to firm-level data. We show that central families were more likely to be accused of participating in the 1991 coup against the democratic Aristide government. We then find that the retail prices of staple goods that are imported by such elites differentially increase during subsequent periods of nondemocracy. Our results suggest that elite social structure is an important factor in democratic reversals.
\end{abstract}

\section{INTRODUCTION}

B etween 1960 and 2010, 51 countries experienced a total of 71 democratic reversals (Acemoglu et al. 2019). Existing theories suggest that reversals occur when democracy threatens the interests of elites who have the power to overthrow it. When elites control a greater proportion of wealth or are invested in activities that can be easily taxed, the policy choices of the masses under democracy are more likely to create economic incentives for elites to oppose democracy.

Ultimately, reversals take place when a group of elites, whether military commanders, a political faction, or the wealthy, collectively organize to overthrow or undermine a government. We argue that within these groups, social networks are important for coordinating activities or spreading information and that network positions create variation in the amount of influence that individuals have over the behavior of others. Despite the considerable focus on social networks in other areas of collective action, the role of elite social networks in organizing resistance to democracy has so far received little attention.

In this article we undertake to our knowledge the first investigation of the role of social networks in coups. We develop a game theoretic model of coups in the spirit of Acemoglu and Robinson (2001; 2006;

Suresh Naidu, Professor, Department of Economics/SIPA, Columbia University, sn2430@columbia.edu.

James A. Robinson (D), Professor, Harris School of Public Policy and Department of Political Science, University of Chicago, jamesrobinson@uchicago.edu.

Lauren E. Young $\mathbb{D}$, Assistant Professor, Department of Political Science, University of California, Davis, leyou@ucdavis.edu.

Received: October 13, 2017; revised: February 19, 2020; accepted: March 29, 2021. First published online: May 21, 2021.
2008), extended to include social networks as modeled by Ballester, Calvó-Armengol, and Zenou (2006). There are three types of agents: citizens, elites, and a potential dictator. ${ }^{1}$ The economy features a fixed number of industries, each inhabited by a subset of elites. The median voter, a citizen, determines policy in democracy and prefers competitive markets. Elites, however, prefer entry barriers that allow them to raise prices. To achieve this they can exert effort toward a coup to place a dictator in power. Elites are interconnected via a social network, and we assume that their actions are strategic complements. The incentive to mount a coup is that if democracy falls, the dictator levies "taxes" as barriers to entry to generate rents for elites.

The model has an important implication that we take to the data. In particular, the incentive of an elite agent to put effort into making a coup happen is an increasing function of their network (Bonacich) centrality. Intuitively, the more central an elite is in the network the more influence his actions have on the actions of others and the more likely it is that he can make a coup happen. We further show that industries in which the coupparticipating elites engage should see their prices rise.

To test these hypotheses we constructed several original Haitian datasets, which we describe in the Section titled "Data." There were a number of motivations for testing the theory in Haiti. First, after the 1991 coup against the democratically elected government of JeanBertrand Aristide, the US Treasury Department published a targeted sanctions list that named individual elites associated with the coup. This list was created based on intelligence efforts by the US government and thus gives us a rare list of people specifically accused

\footnotetext{
${ }^{1}$ We use the terms "dictatorship" and "autocracy" to refer to any state of nondemocracy.
} 
of contributing to a coup. Second, there are rich genealogical sources for Haiti that allow us to understand the social networks of elite families and map elite family involvement in business and politics back to the nineteenth century. Moreover, Haiti is sufficiently small that there is some hope of constructing a relatively complete network. Third, given our focus, it is advantageous that there is variation in regime type because of frequent coups and transitions. Finally, the fact that much of the Haitian elite's wealth stems from imports gives us a rare view of much of the economy because it is easier to access data on international trade than on domestic commerce or production.

We use these data in two primary ways. First we estimate the probability that a particular elite was accused of contributing to the 1991 coup. Our data allow us to examine the relationship between centrality and coup contribution (we drop "accused" from now on) conditional on economic interests, social characteristics, and past political involvement. Our main result is consistent with the model: the probability that a family contributed to the coup is increasing in a range of centrality measures. While our analysis allows us to control for many plausible potential confounding factors, including a family's "neighborhood" in the network, and assess robustness to reverse causality and unobserved confounding, these results should ultimately not be interpreted as conclusive evidence of a unidirectional causal relationship.

Next we test whether coup contributions were rewarded with economic rents under autocracy. We use a dynamic panel data model to estimate the differential effect of an autocratic spell from 2004 to 2006 on the retail prices of products imported by families who contributed to the 1991 coup. We find robust evidence that the prices of goods imported by coup contributors increased relative to those of nonparticipants during autocracy.

Though we only have rich data on elite networks in Haiti the model does make predictions about the types of elite social networks that would tend to enable democratic reversals. When elite centrality is highly right-skewed, it should facilitate the organization of coups, all else being equal. Intuitively, the larger the total centrality of potential coup contributors, the more likely that a coup will happen.

Our article is related to several other contributions. Our basic theoretical results on the connection between network centrality and coups are applications of ideas first proposed by Ballester, Calvó-Armengol, and Zenou (2006) and Galeotti et al. (2010). Our model is also related to other models of coups, in particular Acemoglu, Ticchi, and Vindigni (2010) who focus on the military. Although most of the literature on autocratic persistence has focused on institutions, Carter (2014) shows how the president of Congo-Brazzaville manipulated elite social networks to maintain power. Our approach to measuring the power of elite agents builds on a rich tradition in sociology, including Padgett and Ansell's (1993) seminal study of the Medici family in medieval Florence (see also Puga and Trefler 2014). We also build on recent applications of network analysis in political science (Cruz, Labonne, and Querubin 2017; König et al. 2017). ${ }^{2}$ Finally, our argument that the social cohesiveness of economic elites enables them to organize against majority interests has similarities to arguments made about landed elites in India (Anderson, Francois, and Kotwal 2015).

This article adds to our understanding of democratic reversals by highlighting the importance of elite social networks in facilitating action against democracy and redistribution. Classic research on social movements has highlighted the importance of social networks that link social movement organizers to important resource bases and help overcome collective action problems by generating social benefits to participation (Diani and McAdam 2003; McCarthy and Zald 1977; Zald and McCarthy 1987). Elites, however, are often assumed not to have any problems organizing collectively to resist democracy or other social movement goals (Offe and Wiesenthal 1980). Theories that do focus on elite cohesion assume that elite splits stem from differences in preferences, such as a schism between hardliners and moderates, rather than from the lack of social ties that would facilitate coordination between elites with shared interests (O'Donnell and Schmitter 1986).

We also contribute new evidence to arguments that democratic reversals are organized to protect the economic interests of a wealthy elite. Several past studies have found evidence that coups have materialistic motivations (Dube, Kaplan, and Naidu 2011; Mitra, Thomakos, and Ulubaşǒglu 2002) and that elites benefit economically from restrictions of democracy (Mitra, Thomakos, and Ulubasoglu 2002; Naidu 2012) and suffer during expansions (Dasgupta and Ziblatt 2014). By showing how social networks are integral to the pursuit of those economic interests, our research suggests that economic and social explanations of elite action against democracy are complementary. The analysis that we present brings new micro-level empirical evidence to help explain how elites are actually able to pursue their economic interests through the creation of monopoly-granting autocratic regimes.

\section{BACKGROUND ON HAITI}

Haiti is underdeveloped and unequal, with $48 \%$ of its population below the poverty line and a Gini coefficient of 0.41 as of 2012 according to the World Development Indicators. Much of the wealth derives from dependence on international trade, the ownership and control of which is very concentrated, something that dates back to its preindependence period as an extractive slave society. Foreign merchants entered in the late nineteenth century, staying in Haiti as resident aliens to maintain the protection of foreign governments, yet marrying into elite Haitian society to circumvent

\footnotetext{
${ }^{2}$ While we focus on strategic interaction in networks, information diffusion is another important channel by which networks matter, as in García-Jimeno, Iglesias, and Yildirim (2018).
} 
restrictions on foreign ownership of Haitian property (Plummer 1988). According to a reference produced by the US forces during the occupation in the 1910s and 1920s, "The provisional heart, lungs and stomach of the Republic of Haiti, which means literally, agriculture, commerce and industries, from 1804 to 1915 were largely foreigners: Germans, French, Syrians, Belgians and English, with importance in the order named, who cared very little what became of Haiti so long as they got their "bit"” (Jones 1919, 23).

The Duvalier dictatorship after 1957 largely preserved this concentrated economic structure. A long list of industries became monopolies by presidential decree during the 1950s and 1960s: "mineral and petroleum exploration and exploitation, the construction and operation of television stations, the planting and processing of kenaf, sesame, and ramie, the processing of guano, the manufacture of chocolate, a fertilizer industry, the development of casinos and hotels, the construction of a sugar factory, the improvement of the telephone system, etc.” (Rotberg 1971, 210). By 1985, some 19 families held almost exclusive rights to import many of the most commonly consumed products in Haiti. Though some of these families ultimately fell out with Duvalier, "outlasting all others were families B, C, D and J [in Appendix Figure A1]. They were the country's principal exporters before, during, and after both Duvaliers" (Fass 1988, 27). One indication of how wealthy these families are is that in 1960 Osvald Brandt bought an entire issue of government bonds (Lundahl 1979, 347).

Democratization threatened the economic interests of these elites. Jean-Bertrand Aristide won the 1991 election with almost $70 \%$ of the vote. Aristide had campaigned on a platform of pro-poor redistribution, and began putting in place policies to give the state a more "interventionist, dirigiste, and even protectionist role in economic development" (Fatton 2002, 113). During the first period of democracy, the Aristide regime increased enforcement of tax collection, including import fees, and arrears (Hallward 2007, 33). As a result, the Direction Générale des Impôts "registered a historic increase in total revenues" (Dupuy 2007, 118). The Aristide government also increased the minimum wage and introduced price controls on products such as rice and wheat (Dupuy 2007; Farmer 1994; Hallward 2007).

The first coup occurred in September 1991, just eight months after Aristide took office and installed a military government under Raoul Cédras. The New York Times reported that some wealthy Haitians offered as much as $\$ 5,000$ apiece to soldiers and police officers for their participation in the coup (French 1991). Farmer quotes one rich businessperson as saying that "everyone who is anyone is against Aristide ... except the people" $(1994,150)$. Hallward $(2007,34)$ writes "During the summer of $1991 \ldots$ the most powerful families in the country - the Brandts, the Mevs, the Apaids, the Nadals-began collecting the millions of dollars they would need in order to pay the army to conduct another coup." The US government, opposed to Aristide's policies but nevertheless concerned with the political violence and migrants, imposed sanctions on the junta and its economic backers. The names that Hallward lists as coup supporters all appear on the sanctions list where there are 16 members of the Brandt family, eight Mevs, seven Nadals, and André Apaid. Indeed, the involvement of these families in coup plotting was not new: as early as 1968 the Brandts, Nadals, and Légers funded an attempted coup against Duvalier (Rotberg 1971, 254).

Aristide returned in 1994 to be replaced by René Préval in 1996. Aristide was reelected in 2001 but ousted by a second coup in 2004, again with the backing of economic elites. Although less is known about which specific families participated in this coup, the top private sector backers were largely the same, and were led by André Apaid, who had played a catalyzing role in 1991. Apaid, along with his brother-in-law Charles Baker (also a sponsor of the 1991 coup), offered to pay gang leaders in Cité Soleil, a poor suburb of Portau-Prince, to turn against Aristide. One gang leader who took up the offer was reportedly paid $\$ 30,000$ and offered a US visa (Hallward 2007; Podur 2013). The elite also institutionalized their opposition to Aristide into a network called the G184 in 2002. Though the group's membership is opaque, G184 events featured the same families that had been sanctioned for the first coup, most obviously the Apaid and Baker families, but also Benoît, Denis, and Gilles (Hallward 2007, 192, 228). Civil society monitors describe the G184 as "a political platform led by the country's small private sector" (Arthur 2005,1). Apaid also apparently had control over the rebels who advanced on Port-au-Prince in 2004: Colin Powell reportedly called Apaid after the rebels took control of Cap Haitien and asked him personally to restrain them (Hallward 2007, 224-225).

Shortly after the 2004 coup, the collection of some taxes paid by elites was suspended (Hallward 2007,261; Schuller 2008). Price controls were lifted, and the price of consumer goods skyrocketed, with the price of rice doubling within five months (Hallward 2007, 261; Weiner 2004). Appendix F includes a timeline of events that are relevant to our empirical strategy.

\section{MODEL}

\section{Demographics, Preferences, and Production Structure}

We develop a model to formalize the connection between coup participation and network position. There are three types of agents that play roles in the model, citizens, elites, and a potential dictator. In a democracy the preferences of the citizens determine policy, but a dictator can set a different policy to create profits for elites that can incentivize them to overthrow democracy.

Let $\mathscr{C}$ and $\mathscr{E}$ denote the sets of citizens and elites, respectively. There are $E$ elites in total, so $|\mathscr{E}|=E$, where $|S|$ denotes the cardinality of set $S$, and we use $e \in \mathscr{E}$ to refer to a representative elite. Similarly, $|\mathscr{C}|$ to ensure that the median voter in a democracy will be a 
citizen. Citizen/consumers have a standard CobbDouglas utility function defined over $M$ different goods:

$$
U_{i}=\prod_{m=1}^{M} x_{i m}^{\alpha_{m}}
$$

where $x_{i m}$ is the consumption of good $m$ by agent $i$ and $\alpha_{m}$ is the share of income spent on good $m$, where $\sum_{m=1}^{M} \alpha_{m}=1$. Since it does not play an important role in the analysis, we let $\alpha_{m}=\alpha$ for all $m$, and thus $\alpha=$ $1 / M$. Let $x_{m}$ be the aggregate demand for good $m$. The only economic action that citizens take is to allocate their exogenous income between the different goods. Each agent maximizes this utility function subject to the budget constraint $\sum_{m=1}^{M} p_{m} x_{i m} \leq Y$, where $p_{m}$ is the price of good $m$ and $Y$ is the income of citizen $i$ in terms of the numeraire that we treat as exogenous and identical for all citizens. Standard arguments imply that the Marshallian demand function for good $m$ can be written as $x_{m}=L x_{i m}=\frac{L Y}{M p_{m}}$ because there is mass $L$ of citizens.

Elites own firms distributed across the different sectors and can also take actions to overthrow democracy and install the potential dictator. We assume that each good is produced by a sector and that there are multiple elites in each sector, but this varies across sectors and is fixed. We assume that each good can be produced with a constant returns to scale technology with fixed marginal cost $\kappa$. However, elite producers are also capacity constrained and can produce in total $q_{m}$ units of output in a sector $m$. For simplicity we assume $q_{m}=q$ for all $m$. We assume later that for all sectors total elite supply is less than the total demand for that good, so we do not have to consider rationing schemes across elites.

In addition to the elite producers in a sector, there is also a competitive fringe of firms who have access to the same technology. The equilibrium in each sector without any government intervention therefore will involve elites limit pricing and setting their prices equal to $\kappa$, and profits are zero for each elite in each sector. However, we allow the government to set a "tax" of $\tau_{m}$ that varies across sectors, which raises the marginal cost of the fringe producers only, and this allows the elite to increase the prices they can set. We interpret $\tau_{m}$ as a generic entry barrier (e.g., privileged access to imports, government regulations), which makes it more costly for fringe producers to produce good $m$, thus allowing incumbent elites to raise prices and extract rents. Thus with government intervention, the limit price will be $p_{m}=\tau_{m} \kappa \geq \kappa$ and profits of a particular elite member $e$ who produces in sector $m$ will be $p_{m} q-\kappa q$ or $\left(\tau_{m}-1\right) q \kappa \geq 0$, and clearly profits of elite agent $e$ in sector $m$ are increasing in the tax levied on the fringe producers in that sector. The total profits of the elite in sector $m$ are $\pi\left(\tau_{m}\right)$, and we define $\pi_{e}=$ $\sum_{m=1}^{M} w_{e m} \pi\left(\tau_{m}\right)$, where $w_{e m}$ is the share of total profits in industry $m$ that accrues to elite $e$. Total elite profits will be $\sum_{e=1}^{E} \pi_{e}=\sum_{e=1}^{E} \sum_{m=1}^{M} w_{e m} \pi\left(\tau_{m}\right)$.
We assume for simplicity that taxation is costless and that the tax rate takes on only two values $\tau_{m} \in\left\{1, \bar{\tau}_{m}\right\}$ in sector $m$.

Finally we assume that the potential dictator is "Downsian" and gets exogenous rents $D$ from holding office. At the start of the game he promises the elite a tax vector (with commitment).

We can now write the indirect utility of a citizen in a democracy as a function of the policy vector $\tau$, to be defined shortly, which is

$$
W^{i}(\tau)=\prod_{m=1}^{M}\left(\frac{Y}{M \tau_{m} \kappa}\right)^{\frac{1}{M}} .
$$

The payoff to every elite member $e$ in democracy is $\sum_{m=1}^{M} w_{e m}\left(\tau_{m}-1\right) q \kappa$, which is the sum across all sectors of the economy in which that elite member is active, taking into account the tax set in those different sectors.

\section{Political Regimes, Network Structure, and Transitions}

There are two possible political regimes, democracy and dictatorship. We assume that democracy is the default and applies unless a coup is attempted and succeeds. In a democracy, we will assume that policy is chosen by the median voter, a citizen/consumer, whereas in a dictatorship it will be chosen by the dictator.

Transitions between democracy and dictatorship can occur because the elite can use their de facto power to induce a coup. In particular, suppose that elite $e \in \mathcal{E}$ spends an amount $a_{e} \in[0,1]$ as a contribution to activities to make a coup happen. We can interpret this action in different way-for example, it could involve giving the dictator money to bribe the army or hire paramilitaries directly, both of which have certainly played a role in Haiti. If the elite take actions in this way, then their aggregate "power" to place the dictator in power is

$$
P^{\mathcal{E}}\left(a_{e}, a^{-e}\right)=\frac{1}{E}\left(a_{e}+\sum_{e^{\prime} \neq e} a_{e^{\prime}}\right),
$$

where $a_{e}$ is the action choice of elite member $e$ and $a^{-e}$ the vector of actions of elite members other than $e$, and the notation $\sum_{e^{\prime} \neq e^{\prime}} a_{e^{\prime}}$ means summation over all elite agents except agent $e$. The scaling factor $\frac{1}{E}$ is added simply to make sure we have a well-defined probability of a coup below because it guarantees that the sum of the actions is always between 0 and 1 . There is a cost associated with action $a_{e}$ that is captured by the function $\chi\left(a_{e}\right)$, which takes the specific form

$$
\chi\left(a_{e}\right)=-\sum_{e^{\prime} \neq e} \omega_{e e^{\prime}} a_{e^{\prime}} a_{e}+\gamma a_{e}+\delta \frac{a_{e}^{2}}{2},
$$

where $\delta$ and $\gamma$ are positive constants which are the same for all agents. 
Equation 4 has a usual linear and quadratic term in the own action of elite $e$, the term $\gamma a_{e}+\delta \frac{a_{e}^{2}}{2}$, but it also includes an interaction term so that if the action of player $e$ increases, the marginal cost of exerting effort for player $e^{\prime}$ falls if the two agents are connected in the elite social network. This is so if $\omega_{e e^{\prime}} \neq 0$, and we shall assume that $\omega_{e e^{\prime}}>0$ for all $e e^{\prime}$, which guarantees that the action choices of the elite are strategic complements. The $E \times E$ matrix whose entries are the individual $\omega_{e e^{\prime}}$ is the (weighted) adjacency matrix, which shows the network interactions between the elites. The combination of Equation 3 and Equation 4 means that our model is an adaption of the preferences proposed by Ballester, Calvó-Armengol, and Zenou (2006; see also Jackson 2008, Section 9.5.2) to the technology for generating de facto political power. We assume this technology is the same in democracy and nondemocracy. The formula in Equation 4 brings out the network interactions between the actions of the different elite members and the formula builds in that these actions are strategic complements. We do not take a strong stand on the source of the complementarity in actions among the elite. Information flows, trust, or altruism could all generate situations where elite actions were strategic complements. In addition, interconnected elites may internalize each other's economic interests.

Whether or not a coup succeeds depends on whether the power of the elite is greater than the power of the citizens (as in Acemoglu and Robinson 2008). Because we assume that the citizens are too numerous to solve the collective action problem, this power is not systematically organized, but nevertheless in idiosyncratic circumstances the citizens may have some power. We model this as a shock $\theta$, which is drawn from a distribution function $H$ with density function $h$ on support $[0,1]$. Thus the power of the citizens is

$$
P^{\mathcal{C}}(a)=\theta .
$$

Denote the probability that there is a dictatorship next period by $p\left(a_{e}, a^{-e}\right)$. This is the probability that the power of the elite is greater than the power of the citizens, or the probability that $P^{\mathcal{E}}\left(a_{e}, a^{-e}\right) \geq P^{\mathcal{C}}(a)$, which is simply

$$
p\left(a_{e}, a^{-e}\right)=H\left(\frac{1}{E}\left(a_{e}+\sum_{e^{\prime} \neq e} a_{e^{\prime}}\right)\right)
$$

For simplicity and to maintain a linear quadratic structure of payoffs we assume that $H$ is uniform with constant unit density. Shortly it will be useful to use the notation $p(a)$ for $p\left(a_{e}, a^{-e}\right)$, with $a$ referring to the vector of elite action choices.

We do not observe $a_{e}$ in the data, only whether or not an elite ends up on the sanctions list, discussed below in the data section. Therefore we think of $a_{e}$ as a latent variable and posit a strictly increasing function $F$ : $[0,1] \rightarrow[0,1]$, which is the probability that an elite who took action $a_{e}$ ends up on the sanctions list. We do not assume that being sanctioned leads to any costs, though this could be introduced into the optimization problem of elites without altering the thrust of our argument (though obviously the details would change).

\section{Timing of Events}

We now explain the timing of events. The beginning state is democracy, and there is an opportunity to transition to dictatorship.

1. The potential dictator promises the elite the tax vector $\tau \in\left\{1, \bar{\tau}_{m}\right\}^{M}$ if a coup takes place.

2. Each elite agent $e \in \mathcal{E}$ simultaneously chooses $a_{e} \in[0,1]$ and $P^{\mathcal{E}}\left(a_{e}, a^{-e}\right)$, which is determined according to Equation 3.

3. The random variable $\theta$ is drawn from the distribution $H$, and $P^{\mathcal{C}}$ is determined according to Equation 5.

4. If $P^{\mathcal{E}} \geq P^{\mathcal{C}}$, democracy collapses, the dictator takes power, and the taxes chosen at stage (1) are implemented; if $P^{\mathcal{E}}<P^{\mathcal{C}}$, democracy survives and the tax vector is chosen by the median voter. Taxation and consumption takes place.

\section{Analysis of the Model}

We calculate the pure strategy subgame perfect Nash equilbrium of the game by backward induction.

Note first that if the attempted coup fails or there is no attempt, the median voter, a citizen, sets taxes in a democracy. Since taxes increase the prices of consumption goods and are costly to raise, it is immediate that taxes are zero in a democracy and all elites make zero profits. Indeed, it is easy to see that the indirect utility of citizens is strictly decreasing in $\tau$.

Taking the postcoup tax vector as given and zero profits in a democracy, we move backward to the decision by elites about how much effort to allocate to inducing a coup. Given the tax rates that occur if a coup occurs, the expected payoff for elite $e$ is

$$
H\left(\frac{1}{E}\left(a_{e}+\sum_{e^{\prime} \neq e} a_{e^{\prime}}\right)\right) \sum_{m=1}^{M} w_{e m}\left(\tau_{m}-1\right) q \kappa+\sum_{e^{\prime} \neq e} \omega_{e e^{\prime}} a_{e^{\prime}} a_{e}-\gamma a_{e}-\delta \frac{a_{e}^{2}}{2} .
$$

Assuming there is an interior equilibrium, the resulting first-order condition for elite agent $e$ is

$$
\sum_{e^{\prime} \neq e} \omega_{e^{\prime} e} a_{e^{\prime}}-\gamma-\delta a_{e}+\frac{1}{E}\left[\sum_{m=1}^{M} w_{e m}\left(\tau_{m}-1\right) q \kappa\right]=0 .
$$

Now we can write Equation 7 for all elite agents as a matrix equation

$$
a=\Pi+\frac{1}{\delta} \omega a
$$

where $a=\left(a_{1}, . ., a_{E}\right)$ is a column vector of action choices by active elites, $\omega$ is the adjacency matrix, and $\Pi$ is the (weighted) active elite net profit vector defined as 


$$
\Pi \equiv \frac{1}{\delta E}\left(\sum_{m=1}^{M} w_{1 m}\left(\tau_{m}-1\right) q \kappa-\gamma, . ., \sum_{m=1}^{M} w_{E m}\left(\tau_{m}-1\right) q \kappa-\gamma\right) .
$$

We can write the solution to Equation 7 in matrix notation as

$$
a=\left(\mathbf{I}-\frac{1}{\delta} \omega\right)^{-1} \Pi
$$

where $\mathbf{I}$ is the identity matrix. Note that because of the network structure, the optimal choice of $a_{e}$ depends on the tax rate set in a particular sector not just via own profits but also through the profits of elite agents who are connected to $e$ in the adjacency matrix.

As Ballester, Calvó-Armengol, and Zenou (2006) show (Theorem 1 and Remark 1), this implies that the action choice of agent $e$ can be written as their weighted Bonacich centrality, with weights given by weighted profits as in Equation 8.

Finally, to complete the analysis, moving back to the initial node of the game, because the dictator is Downsian, his objective in choosing the tax vector is to maximize the probability that a coup happens, which is $\sum_{e=1}^{E} a_{e}$. Because taxation is costless, it is clear that he will offer the maximal tax vector.

There remain several technical issues to address. First we need to make sure that the choice of $a_{e}$ is interior. It is sufficient to show that the matrix $I-\frac{1}{\delta} \omega$, or equivalently its inverse, is positive definite, and thus it is sufficient to show all its eigenvalues are positive (since $\omega$ is symmetric). This would follow if the maximal eigenvalue of $\omega$, which we denote $\lambda$, is less than $\delta$, which we empirically impose below. Second we need to guarantee that no elite producer is unincentivized by tariff benefits because they are already providing the maximum level of effort $a=1$. We discuss this condition in the Appendix.

From this the first result, which is a direct consequence of Ballester, Calvó-Armengol, and Zenou (2006), Theorem 1, follows

Proposition 1: The equilibrium action of elite agent $e$ is increasing in his weighted Bonacich centrality.

From this and the structure of our model, we have our main result which we take to the data.

Corollary 1: The probability that an elite agent $e$ is sanctioned for participation in the coup is increasing in his weighted Bonacich centrality.

Corollary 1 is the main theoretical result we can test with our data in the first set of empirical tests. It is also interesting to consider what the model tells us about the payoffs to elites from making a coup happen. In the model, the incentive to take actions to induce a coup is that elites get entry barriers so that they experience higher prices after the coup.

A natural conjecture would be that those who were sanctioned by the US would receive the most favorable treatment after the coup because they likely put more effort into it.
We can express this formally as the sample covariance between the vector of tariffs and the ownershipweighted vector of coup participation.

There are two things to note about this result. First is that this result is not a mechanical result of higher incentives (via $\tau_{m}$ ) resulting in higher effort by elites. Instead, the effort of elites is increasing in their exposure to promised tariff despite the fact that the elite effort depends on the effort of their neighbors in the network. Second is that while we present a transparent sufficient condition below, in Appendix C.1 we provide a weaker sufficient condition for the covariance to be positive.

Proposition 2: If $\left(I-\frac{1}{\delta} \omega\right)^{-1}$ is positive definite and the average maximum tariff $E[\bar{\tau}] \equiv \frac{1}{M}>1$ is sufficiently close to 1 , then $\operatorname{Cov}\left(\tau, \sum_{e} w_{e m} a_{e}\right)>0$.

Proof: Let $W$ denote the $E \times M$ matrix of ownership shares, and $\Omega \equiv\left(I-\frac{1}{\delta} \omega\right)^{-1}$. Multiply both sides of the equilibrium condition (Equation 9 ) by the transpose of $\Pi=W\left(\tau-1_{\mathrm{M}}\right) q \kappa-\gamma 1_{E}$ to get

$$
\begin{gathered}
\left(W\left(\tau-1_{\mathrm{M}}\right) q \kappa-\gamma 1_{E}\right)^{\prime} \Omega\left(W\left(\tau-1_{\mathrm{M}}\right) q \kappa-\gamma 1_{E}\right) \\
=\left(W\left(\tau-1_{\mathrm{M}}\right) q \kappa-\gamma 1_{E}\right)^{\prime} a .
\end{gathered}
$$

Note that the left-hand side is greater than 0 by $\Omega$ being positive definite. We can then expand the righthand side to get

$$
\left.0<W\left(\tau-1_{\mathrm{M}}\right) q \kappa-\gamma 1_{E}\right)^{\prime} a=q \kappa \tau^{\prime} W^{\prime} a-q \kappa 1_{\mathrm{M}}{ }^{\prime} W^{\prime} a-\gamma 1_{E}^{\prime} a,
$$

which implies

$$
0<\tau^{\prime} W^{\prime} a-1_{\mathrm{M}}^{\prime} W^{\prime} a-\frac{\gamma}{q \kappa} 1_{E}^{\prime} a .
$$

Now by assumption, if $E[\tau]$ is sufficiently close to 1 , we will have

$$
\begin{gathered}
0<\tau^{\prime} W^{\prime} a-1_{\mathrm{M}}{ }^{\prime} W^{\prime} a-\frac{\gamma}{q \kappa} 1_{E}^{\prime} a_{e}<\tau^{\prime} W^{\prime} a-E[\tau]\left(1_{\mathrm{M}}{ }^{\prime} W^{\prime} a\right) \\
=M \times \operatorname{Cov}\left(\tau, W^{\prime} a\right),
\end{gathered}
$$

where we recall that the sample covariance of two vectors $x$ and $y$ is $\operatorname{Cov}(x, y)=E[x y]-E[x] E[y]=$ $\frac{x \cdot y}{M}-\frac{\left(1_{M} \cdot x\right)}{M} \frac{\left(1_{M} \cdot y\right)}{M}$, the result.

In the second set of empirical tests, we test this proposition.

\section{DATA}

To test the predictions of our model, we constructed a dataset that brings together information on families, firms, and products from more than 15 different sources. We draw on genealogical data going back to the mid-nineteenth century, contemporary firm-level data, and information on ownership of hundreds of businesses. We describe the data assembly process in 
detail in Appendix A, and in this section we detail the construction of the two most distinctive variables: coup participation and network centrality.

The information on coup participation comes from the US Treasury Department's targeted sanctions list, which named individual official and unofficial leaders in the coup government in power during the early 1990s. The US had sanctions against Haiti from 1991 until the restoration of democracy in 1994 based on an executive order by President Bush and populated with specific individuals by the Office of Foreign Assets Control. Participation in coups is an illicit activity that most participants prefer to hide, and the existence of this list is one reason we chose to test our general theory in Haiti.

The sequence of events suggests that this list represents the US government's best information on which elites were instrumental to installing and supporting the coup government. ${ }^{3}$ Being added to the sanctions list meant that an individual's US assets were frozen, they were barred entry into the US, and they were unable to trade with US partners. From this list, we create a binary measure of coup participation by family.

We do not have a similar list for the second coup in 2004, but the historical literature suggests that the main instigators and supporters were the same and that many were connected by kinship and social ties. Many elite families identified as supporters of the second coup also appear on the 1991 sanctions list, including the Apaids, Bakers, Benoits, Denis, and Gilles (Hallward 2007; Podur 2013). Therefore, we use the same list of elites when we examine the consequences of the second coup.

Our data on the social structure is taken from the Association Généalogique d'Haïti, a nonprofit effort to collect genealogical data from Haitian and American archives and the personal records of Haitian families run by a business leader in Haiti. ${ }^{4}$ We use the Collective Genealogy of Haitian Families, which includes information on more than 64,000 individual members of Haitian families beginning in the seventeenth century. We restrict this data to more complete cohorts born between 1850 and 1975 and collapse it into a network of marriage links between families. Individuals are identified as being part of a family based on their last names, with women entered into the dataset under their father's name. ${ }^{5}$ Direct marriage ties, including second and subsequent marriages, are coded based on the recorded spouses of individuals associated with each family name. This results in a network with nodes representing families, where the average family in our

\footnotetext{
${ }^{3}$ The text of the Executive Order establishing the sanctions defines it to target those within the regime who provided support to the regime or who obstructed efforts to negotiate a settlement. One Haitian academic told us that the criteria for inclusion were (a) public statements from those individuals, (b) open affiliation with the coup leaders, (c) open support to the anti-Aristide rebels, and (d) human rights reports that documented their involvements.

${ }_{5}^{4}$ Accessible at http://www.agh.qc.ca/.

$597 \%$ of women in our dataset have the same last name as their father.
}

elite sample has 15 recorded marriages out of 21 family members recorded between 1850 and 1975 .

The use of family ties to operationalize a social network is basic to most network analysis. In a country like Haiti, where the state is weak and small, the natural way to organize many activities is through kinship (Henrich and Henrich 2007). Therefore, scholars such as Padgett and Ansell (1993) begin their analyses by constructing kinship and marriage networks. The use of kinship networks is also common in recent political economy studies of the influence of social networks on politics (e.g., Cruz, Labonne, and Querubin 2017). Nevertheless, elite social networks are formed not only through marriages but also through participation in educational, occupational, and social institutions. In a case like Haiti, where family firms dominate, family networks are a reasonable proxy for a wide range of strong social ties and are also likely to shape additional interactions.

An important variable in our model is $\Pi^{e}$, the profits of an elite family $e$ under dictatorship. As an imperfect proxy, we use the sum of values of imports across products $p$ and across businesses $j$, with the latter divided by the number of owners nown $n_{j}, \pi_{e}=$ $\sum_{p} \sum_{j} \frac{\text { value }_{j i p}}{\text { now }_{j}}$. Ideally, we would calculate $\Pi^{e}$ based on data from before the 1991 coup. However, we only have data linking elite families to firms and products for 2009-2011 and thus rely on the assumption that shipping interests have been stable over time. This assumption is supported by the historical literature, which documents how many of the families who show up as having high trade values in our data were also prominent economic players in the 1990s. For example, a 1996 Dow Jones report quoted in Sprague-Silgado $(2018,5)$ reported that "well-known local names such as Mevs, Bigio, Brandt, Madsen and Acra have run the economy since the early days of this century. They control much of Haiti's industry and trade; its supplies of petroleum, telephones, sugar, flour, plastics, soap, cooking oil, cement, steel, iron."

Nevertheless, to check this assumption we test the extent to which the value and volume of a good imported by a specific family in 2009 and 2011 are correlated. This is a relatively tough test given that Haiti experienced a catastrophic earthquake in January 2010 that destroyed the port and massively disrupted trade. Appendix A. 2 shows that for the products that we use in our analyses, the correlations are 0.51 to 0.56 .

We calculate several network statistics implied by our theory, varying the weight placed on close versus distant ties. The most general expression of the centrality measures that we use is the weighted Bonacich centrality, corresponding to Equation 9 above:

$$
B\left(\frac{1}{\delta}, \Pi, \omega\right)=\left(I-\frac{1}{\delta} \omega\right)^{-1} \Pi
$$

where $\omega$ is the adjacency matrix, $\frac{1}{\delta}$ determines the emphasis on close versus distant nodes, and $\Pi$ is defined as above. We use a version of the adjacency matrix 
where links between families are weighted by the size of each family such that links to a large family with many potential marriages contribute less to centrality than a link with a small family. ${ }^{6}$ Each element of the adjacency matrix is multiplied by $\frac{1}{\text { size }_{e} \times \text { size }_{m}}$, where size $e_{e}$ is the number of individuals in family $e$ and size $e_{m}$ is the number of individuals in family $m$. Bonacich (1987) suggests that $\frac{1}{\delta}$ take the value in the range $\left(0, \frac{1}{\lambda}\right)$, where $\lambda$ is the largest eigenvalue of the adjacency matrix $\omega$, in a network with complementarities. This ensures that $\lambda<\delta$, and so the matrix $I-\frac{1}{\delta} G$ is positive definite, which was required for our theoretical results above. Our primary measure of network centrality is the Bonacich centrality where $\frac{1}{\delta}=\frac{1}{5 \lambda}=0.1$, because the largest eigenvalue of $G$ is approximately $\lambda=2$, but we also show that our results hold when we parameterize the Bonacich centrality with values in the range $\frac{1}{\delta} \in\left[\frac{1}{10 \lambda}, \frac{9}{10 \lambda}\right]$. We can use the data to provide an auxiliary check on the magnitude of $\frac{1}{\delta}$ by regressing a family's coup participation on the coup participation of its direct connections, recovering an estimate of the direct spillovers. We find that the coefficient on direct spillovers from this regression, shown in Appendix D.1, implies a value of $\frac{1}{\delta}$ equal to 0.2 , close to our baseline and well within the range of our robustness exercises. The method of calculating Bonacich centrality that is implied by our model identifies a set of central families who correspond with the historical literature on Haiti. The Acra, Brandt, Baker, and Bigio families, known both for their dominance in import markets and coup participation, are near the top of our list of central families. Appendix Table A1 presents information on the 25 most central families in our dataset using our preferred operationalization of centrality.

In addition to these variables, we constructed a number of control variables representing social and economic factors that might be related to coup participation and centrality. To create controls for other social characteristics, we digitized dictionaries of public officials and immigration histories constructed by a Haitian sociologist to create indicators of whether a family was a political or military elite from Haiti's independence to the end of the Duvalier dictatorship, as well as indicators of whether their ancestors immigrated to Haiti after independence (Supplice 2001; 2009). To create controls for economic factors, we draw on eight different sources. We create a measure of the consumption share (a proxy for inelasticity) from Jensen, Johnson, and Stampley's (1990) data on household consumption in Haiti, and the value of trade is from a Haitian trading association called AGEMAR. The product measures cover five characteristics, described in the data appendix, that have been found in other contexts to affect the vulnerability of economic actors to government predation and taxation. They include divisibility, bulkiness (de la Sierra 2020), time sensitivity (Hummels 2007),

\footnotetext{
${ }^{6}$ It is standard practice in analysis of network data to correct for the "garrulousness," or overall number of connections, of nodes (Bailey et al. 2018).
}

reference price (Rauch 1999), and complexity (Hausmann et al. 2013). When families import more than one product, these characteristics are aggregated up to the family level weighted by the value of the family's import portfolio that each product comprises. Finally, in some specifications we include a community fixed effect that we calculate based on the network data using a fast-greedy community detection algorithm (Clauset, Newman, and Moore 2004). These fixed effects represent a flexible way to control for endogenous network formation by estimating the effect of centrality within subgraphs of nodes that should have similar unobserved characteristics to the extent that connections are endogenously formed. The top panel of Figure 1 shows that coup participants are spread throughout many network neighborhoods. The bottom panel shows that the distribution of centrality is rightskewed, particularly for coup participants, and that for the importer sample in particular there are more highdensity coup participants than nonparticipants.

\section{RESULTS}

\section{Who Participates in Coups?}

In this section we test our prediction that central elites are more likely to organize against democracy. Figure 2 plots the proportion of elites who participated in the coup in the importer-only and all-elite samples, broken down into 10 equally sized deciles of centrality. In the importer sample, $29 \%$ of elites in the lowest centrality decile participated in the coup, compared with $55 \%$ in the highest. In the all-elite sample, $18 \%$ in the lowest decile participated compared with $43 \%$ in the highest.

Figure 2 shows that there is indeed a correlation between elite centrality and coup participation. Is this correlation driven by omitted variables, or does it hold up to the inclusion of controls for other social, political, and economic characteristics of families? To assess the relationship between centrality and coup participation conditional on other relevant characteristics, we estimate the following specification:

$$
\begin{aligned}
\text { Coup }_{i}= & \text { Centrality }_{i}+\eta \text { FamilySize }_{i}+\text { Social }_{i}^{\prime} \theta \\
& + \text { Economic }_{i}^{\prime} \gamma+\varepsilon_{i},
\end{aligned}
$$

where $\operatorname{Coup}_{i}$ is an indicator for whether a family participated in the 1991 coup. Centrality is a measure $_{i}$ of a family's weighted centrality in the marriage network. Social $l_{i}$ is a vector of social characteristics of each family including historical military and political service and migration history. We also control for family size. Economic $_{i}$ is a vector of characteristics that define the economic interest of a family in a coup.

We use two separate datasets at the family level for this analysis: one that includes all elites, meaning any family that appears in our records of historical political or military service or in one of our business ownership databases, and one that covers only importers. Our model, which assumes that elites want to participate 
FIGURE 1. Visualizations of Network Data

(a) Network of importers

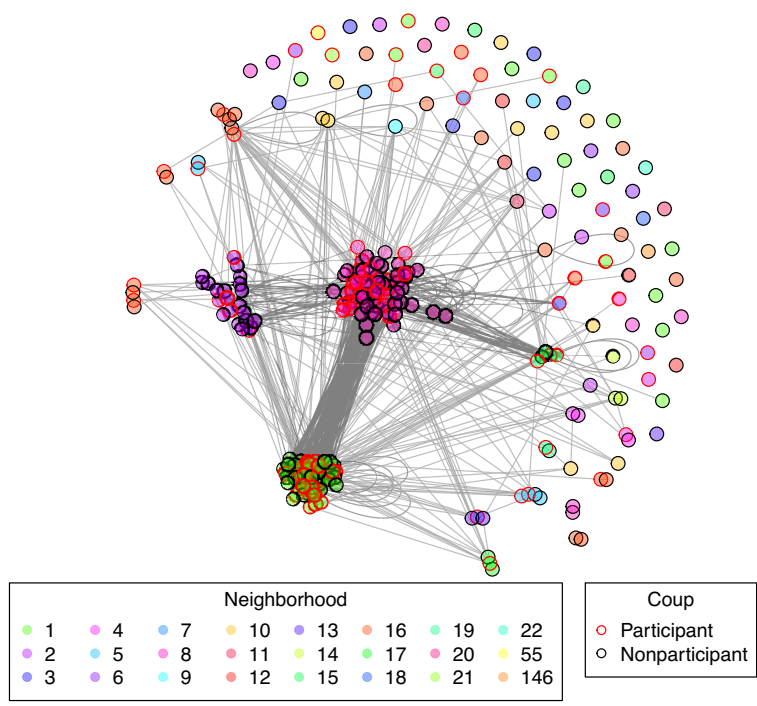

(c) Distribution of importer centrality

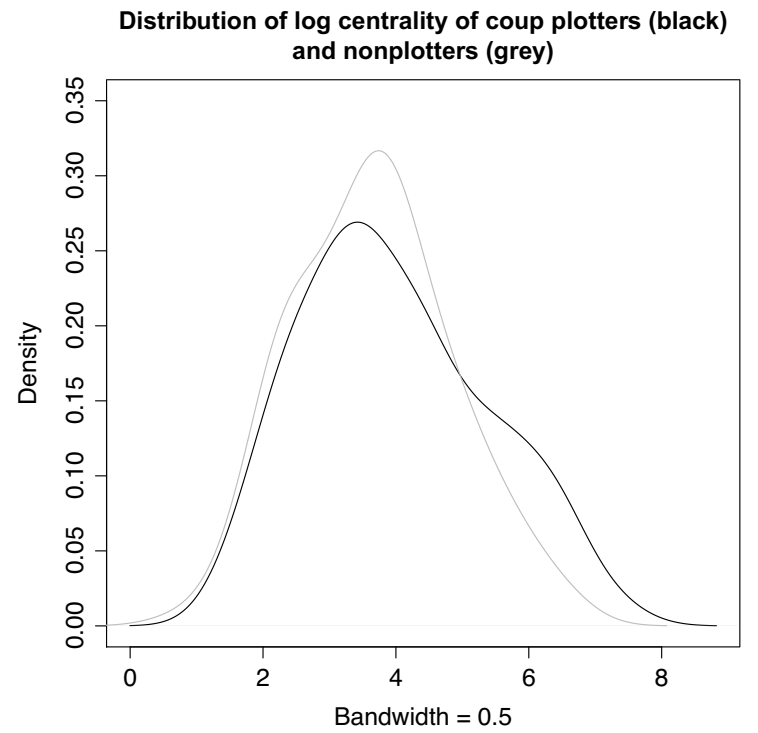

(b) Network of all elite

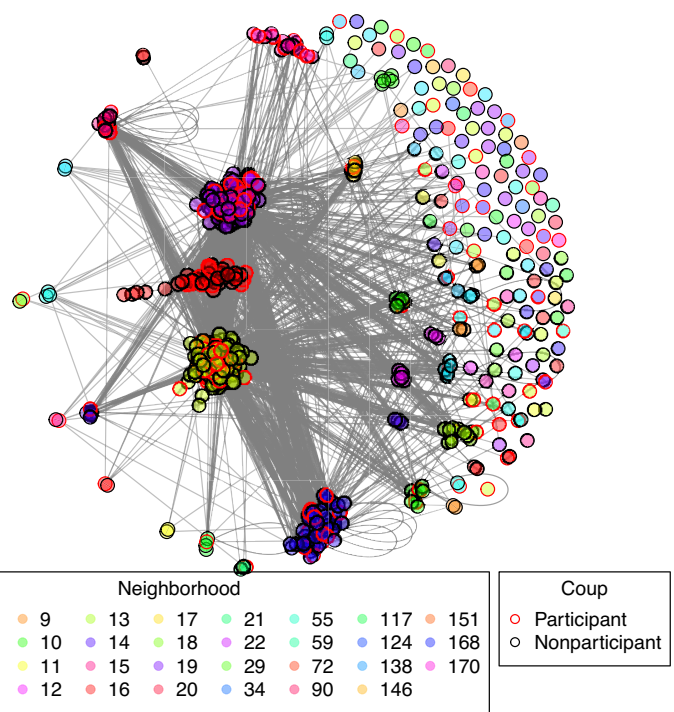

(d) Distribution of all elite centrality

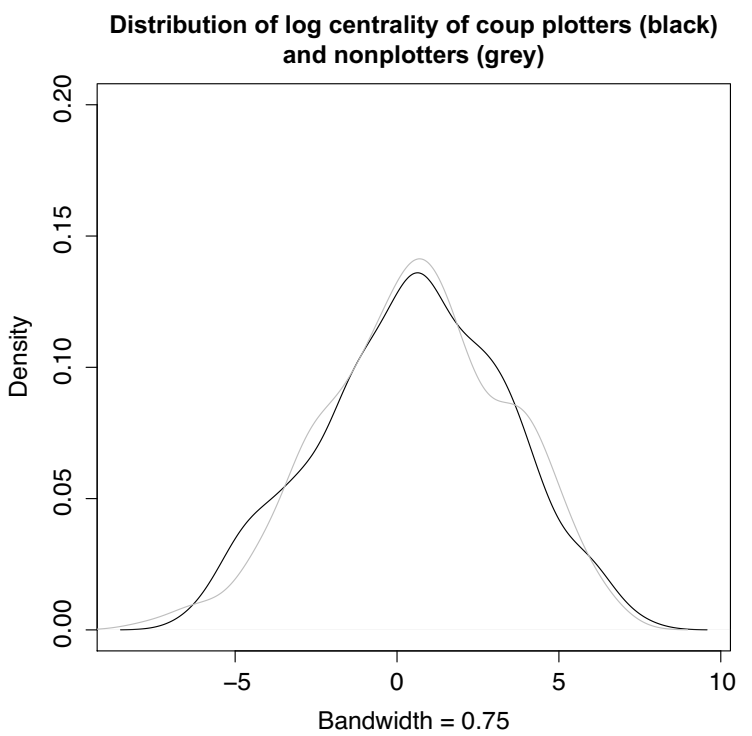

Note: The top panel in this figure shows marriage network ties among importing elites and all elites, with families clustered based on their neighborhood. The bottom panel shows kernel density plots of log centrality among the coup participant and the non-coup-participant families.

in coups to gain tariff protections under autocracy, is tested most directly in the importer sample. In the allelite sample, it is less evident that our assumptions about elites' incentives are descriptively true.

One concern in this analysis is the risk of bias due to omitted variables. In Appendix B, we examine the correlates of centrality and find that obvious determinants of coup participation, such as military or political elite status, are uncorrelated with family centrality conditional on covariates. Nonetheless we control for many possible observable determinants of centrality. We also include network neighborhood fixed effects in some specifications to take into account the fact that families may cluster based on unobserved factors. We calculate these fixed effects using the fast-greedy algorithm, which identifies dense subgraphs within the full network (Clauset, Newman, and Moore 2004). Later in this section, we describe additional robustness checks to assess the risk of omitted variable bias.

Table 1 presents the results of these regressions. Columns 1-6 show the results using data from our importer sample, whereas Columns 7-10 use the full elite sample. Columns 1 and 7 show the bivariate relationship between coup participation and centrality. 


\section{FIGURE 2. Proportion of Elites Who Participate in the Coup by Deciles of Centrality}

(a) Importers

1.00

0.75

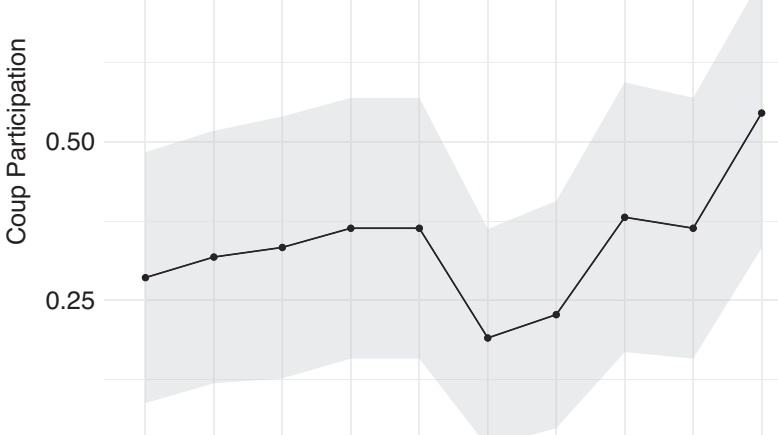

0.00
0.75

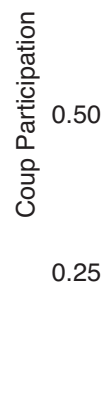

0.00 (b) All elite

1.00

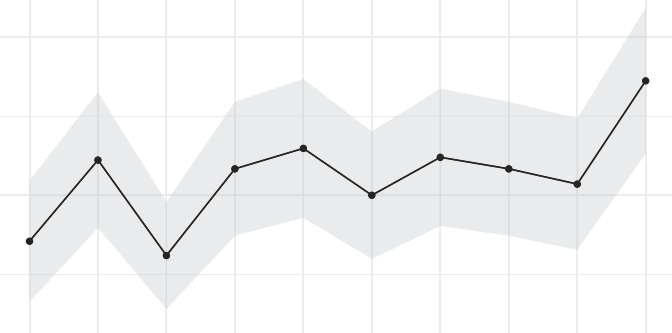

$\hat{0}$

Note: This figure shows the percentage of families who appear on the OFAC list by our weighted centrality measure.

Columns 2 and 8 add a control for family size, and Columns 3-6 and 9-10 add four other social characteristics - namely, whether a family has any historical military and political service, whether a family migrated to Haiti after independence, and whether they migrated from the Middle East. Columns 4-6 include our two most important measures of economic interest: the value of a families' trade and a proxy for demand inelasticity. Columns 5-6 include five other product characteristics. Columns 6 and 10 include the network neighborhood fixed effects. Models are estimated using OLS with robust standard errors in parentheses. For our main coefficient of interest, we also present a second estimate of the standard errors that is clustered by the network neighborhood in square brackets.

Table 1 is consistent with the theoretical result that central families are more likely to participate in coups. This result is robust to the inclusion of a wide range of economic measures that should make a family more interested in autocracy. The centrality coefficient remains significant with all the social controls in the importer sample, but falls in magnitude and loses significance with these added in Column 9 in the all-elite sample. The relationship between centrality and coup participation is stronger and more robust in the importer sample, which is consistent with our theoretical argument that network ties facilitate and incentivize collective action by an economic elite with the purpose of protecting monopolies.

Substantively, we find that a one-standard-deviation increase in centrality is associated with a 9-21-percentage-point change in the probability of participating in the coup. This is roughly double the effect of being a military family. The estimates in Column 6 imply that an elite family at the average level of the control variables has a $45 \%$ probability of coup participation at the mean level of centrality, increasing to $62 \%$ with a one-standard-deviation increase in centrality.

We also test whether the relationship between centrality and coup participation is robust to other measures of network centrality. As discussed in the description of our data, our preferred measure of centrality is a case of Bonacich centrality where the $\frac{1}{\delta}$ parameter that sets the weight of close over distant ties is equal to $\frac{1}{5 \lambda}=0.1$, which is similar to our estimate of the relationship between coup degree and coup participation in Appendix D.1. In Figure 3, we recalculate centrality allowing this parameter to approach the largest eigenvalue in the adjacency matrix by allowing $\frac{1}{\delta}$ to vary in the range of $\left[\frac{9}{10 \lambda}, \frac{1}{10 \lambda}\right]$. This puts increasing weight on close over distant connections. Figure 3 plots the coefficient on centrality using the specification in Columns 1 and 7 of Table 1 . All estimates are well within the confidence intervals of our original estimate.

A second check tests whether our results are robust to down-weighting data that appears to be lower quality. We created family-level datasets by assuming that individuals who share the same last name are part of the same family. Thus, one possible source of measurement error comes from misattributing family ties to unrelated individuals who share the same last name. As a measure of data quality, we therefore calculate the probability that there is a path in the individual-level genealogical data between individuals with the same last name. Results in Appendix D.2 show that estimates are robust to weighting observations by this measure of data quality. 


\section{TABLE 1. Coup Participation}

\begin{tabular}{|c|c|c|c|c|c|c|c|c|c|c|}
\hline & \multicolumn{10}{|c|}{ Dependent variable: } \\
\hline & \multicolumn{10}{|c|}{ Coup } \\
\hline & (1) & (2) & (3) & (4) & (5) & (6) & (7) & (8) & (9) & $(10)$ \\
\hline Centrality & $\begin{array}{l}0.188^{* * *} \\
(0.060) \\
{[0.038]}\end{array}$ & $\begin{array}{l}0.178^{\star * *} \\
(0.058) \\
{[0.06]}\end{array}$ & $\begin{array}{l}0.199^{\star \star \star} \\
(0.065) \\
{[0.044]}\end{array}$ & $\begin{array}{c}0.127^{*} \\
(0.072) \\
{[0.066]}\end{array}$ & $\begin{array}{c}0.136^{\star} \\
(0.073) \\
{[0.015]}\end{array}$ & $\begin{array}{l}0.169^{* *} \\
(0.071) \\
{[0.119]}\end{array}$ & $\begin{array}{l}0.209^{\star * *} \\
(0.055) \\
{[0.066]}\end{array}$ & $\begin{array}{l}0.193^{\star * *} \\
(0.054) \\
{[0.025]}\end{array}$ & $\begin{array}{c}0.099 \\
(0.064) \\
{[0.052]}\end{array}$ & $\begin{array}{c}0.086 \\
(0.064) \\
{[0.126]}\end{array}$ \\
\hline Family size & & $\begin{array}{l}0.066^{\star \star \star} \\
(0.022)\end{array}$ & $\begin{array}{l}0.065^{\star \star \star} \\
(0.022)\end{array}$ & $\begin{array}{l}0.055^{\star \star} \\
(0.026)\end{array}$ & $\begin{array}{l}0.052^{\star \star} \\
(0.026)\end{array}$ & $\begin{array}{l}0.057^{\star} \\
(0.031)\end{array}$ & & $\begin{array}{l}0.045^{\star * *} \\
(0.012)\end{array}$ & $\begin{array}{l}0.035^{\star \star \star} \\
(0.013)\end{array}$ & $\begin{array}{l}0.036^{\star \star \star} \\
(0.014)\end{array}$ \\
\hline Value & & & $\begin{array}{c}-0.014 \\
(0.030)\end{array}$ & $\begin{array}{c}-0.016 \\
(0.030)\end{array}$ & $\begin{array}{c}0.003 \\
(0.036)\end{array}$ & $\begin{array}{c}-0.007 \\
(0.044)\end{array}$ & & & & \\
\hline Consumption & & & 0.025 & 0.023 & 0.017 & 0.012 & & & & \\
\hline Share & & & $(0.051)$ & $(0.046)$ & $(0.050)$ & $(0.056)$ & & & & \\
\hline All inputs & & & $\begin{array}{c}-0.029 \\
(0.141)\end{array}$ & $\begin{array}{c}0.002 \\
(0.145)\end{array}$ & $\begin{array}{c}0.176 \\
(0.185)\end{array}$ & $\begin{array}{c}0.201 \\
(0.200)\end{array}$ & & & & \\
\hline Political elite & & & & $\begin{array}{c}0.074 \\
(0.084)\end{array}$ & $\begin{array}{c}0.071 \\
(0.084)\end{array}$ & $\begin{array}{c}0.067 \\
(0.090)\end{array}$ & & & $\begin{array}{c}0.067 \\
(0.045)\end{array}$ & $\begin{array}{c}0.062 \\
(0.047)\end{array}$ \\
\hline Military elite & & & & $\begin{array}{c}0.079 \\
(0.100)\end{array}$ & $\begin{array}{c}0.088 \\
(0.104)\end{array}$ & $\begin{array}{c}0.080 \\
(0.106)\end{array}$ & & & $\begin{array}{l}0.126^{\star \star *} \\
(0.037)\end{array}$ & $\begin{array}{l}0.101^{\star \star \star *} \\
(0.038)\end{array}$ \\
\hline Business elite & & & & & & & & & $\begin{array}{c}0.057 \\
(0.044)\end{array}$ & $\begin{array}{c}0.057 \\
(0.045)\end{array}$ \\
\hline Middle Eastern & & & & $\begin{array}{c}0.168 \\
(0.121)\end{array}$ & $\begin{array}{c}0.171 \\
(0.125)\end{array}$ & $\begin{array}{c}0.149 \\
(0.140)\end{array}$ & & & $\begin{array}{l}0.249^{\star \star \star} \\
(0.096)\end{array}$ & $\begin{array}{l}0.224^{\star \star} \\
(0.102)\end{array}$ \\
\hline Immigrant & & & & $\begin{array}{c}0.086 \\
(0.096)\end{array}$ & $\begin{array}{c}0.096 \\
(0.097)\end{array}$ & $\begin{array}{c}0.085 \\
(0.106)\end{array}$ & & & $\begin{array}{c}0.062 \\
(0.059)\end{array}$ & $\begin{array}{c}0.074 \\
(0.061)\end{array}$ \\
\hline Constant & $\begin{array}{l}0.433^{* * *} \\
(0.044)\end{array}$ & $\begin{array}{l}0.263^{\star \star \star} \\
(0.066)\end{array}$ & $\begin{array}{l}0.314^{\star *} \\
(0.135)\end{array}$ & $\begin{array}{c}0.191 \\
(0.146)\end{array}$ & $\begin{array}{c}0.083 \\
(0.163)\end{array}$ & $\begin{array}{c}0.185 \\
(0.178)\end{array}$ & $\begin{array}{l}0.427^{\star * *} \\
(0.042)\end{array}$ & $\begin{array}{l}0.313^{\star * *} \\
(0.050)\end{array}$ & $\begin{array}{l}0.138^{\star *} \\
(0.067)\end{array}$ & $\begin{array}{l}0.200^{\star * \star} \\
(0.077)\end{array}$ \\
\hline $\begin{array}{l}\text { Product chars. } \\
\text { Community FE }\end{array}$ & & & & & $\checkmark$ & $\begin{array}{l}\checkmark \\
25\end{array}$ & & & & 36 \\
\hline Sample & & & $\operatorname{Imp}$ & & & & & & & \\
\hline $\begin{array}{l}\text { Observations } \\
R^{2}\end{array}$ & $\begin{array}{r}217 \\
0.033\end{array}$ & $\begin{array}{r}217 \\
0.069\end{array}$ & $\begin{array}{r}217 \\
0.074\end{array}$ & $\begin{array}{c}217 \\
0.113\end{array}$ & $\begin{array}{r}217 \\
0.132\end{array}$ & $\begin{array}{c}217 \\
0.232\end{array}$ & $\begin{array}{r}716 \\
0.016\end{array}$ & $\begin{array}{r}716 \\
0.033\end{array}$ & $\begin{array}{r}716 \\
0.071\end{array}$ & $\begin{array}{r}716 \\
0.112\end{array}$ \\
\hline
\end{tabular}




\section{FIGURE 3. Coefficients on Centrality Placing Increasing Weight on Close Ties}

(a) Importers

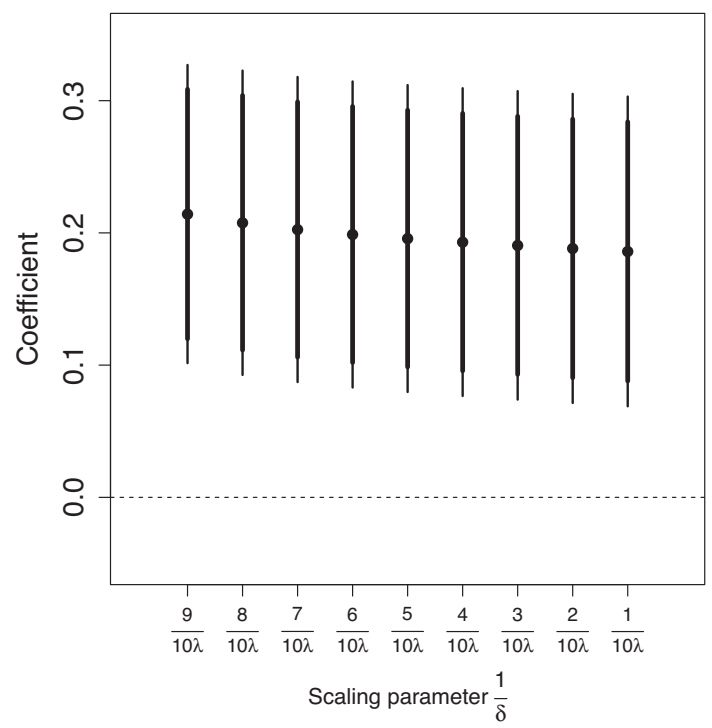

(b) All elite

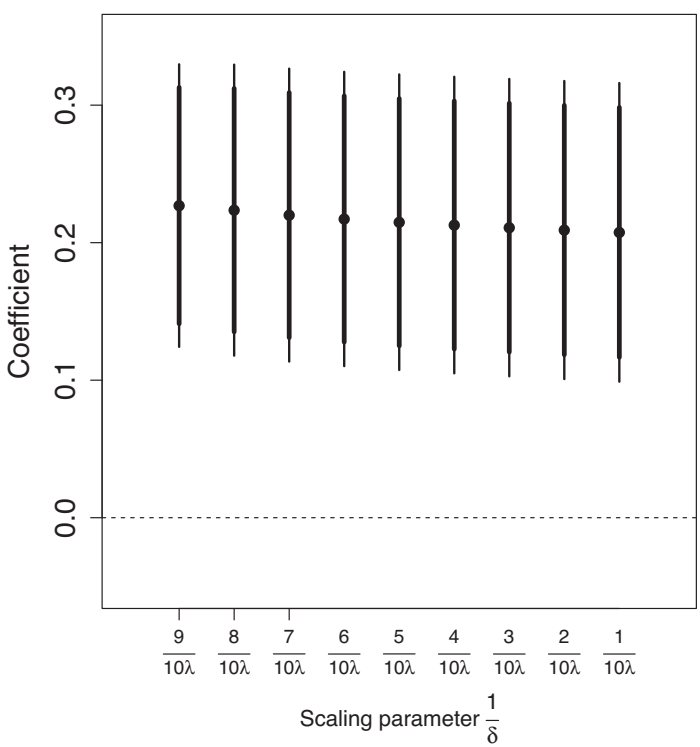

Note: This figure shows how centrality correlates with coup participation for different choices of the weighting parameter $\frac{1}{\delta}$. Panel A shows this among importing elites while Panel B shows this for all elites.

We have shown that the results are reasonably robust across a range of specifications and ways of operationalizing our key variables. However, because we have not manipulated network centrality, the coefficients are not estimating causal effects. How plausible is it that these correlations are driven by reverse causality or omitted variable bias?

As a first attempt at minimizing omitted variable bias, we controlled for many plausible economic and social characteristics that could drive coup participation. In addition, we included fixed effects that indicate the community of each family in the network to control in a coarse way for endogenous network formation, as there may be groups of families that intermarry due to unobservable similarities such as charisma or wealth. These fixed effects increase the $R^{2}$ considerably but do not alter the coefficient on centrality. The fact that centrality predicts coup participation even within these clusters suggests that it is in fact centrality of individual families, not broad unobserved family characteristics, that is driving our results.

Second, we conduct a sensitivity analysis to assess the strength of omitted variables that would be needed to explain our coefficients. We use a methodology proposed by Altonji, Elder, and Taber (2005) and elaborated by Oster (2019) that enables identification of the strength of omitted variables in terms of their relationship to the existing included controls that would be needed to explain the observed effect under reasonable assumptions about $R^{2}$ movements. This analysis is presented in Appendix D.4. It shows that the coefficients on centrality from the importer and all elite samples cannot be fully explained by unobserved heterogeneity under the assumptions recommended by Altonji, Elder, and Taber (2005) and Oster (2019). Using Oster's (2019) recommended assumption for the maximum $R^{2}$ value, unobserved omitted variables would have to be 2.3 times as important in explaining the variation in the independent variable as the observed controls to explain the coefficient in the importer sample, and 1.2 times in the all elite sample, passing the suggested bar for robustness.

In addition to omitted variable bias, these correlations could be driven by reverse causality if participating in coups causes families to intermarry. The results are similar in magnitude and significance if we cut off the network at cohorts born before 1950 and 1925. These results are presented in Appendix D.5.

Finally, one concern with analyses using network data is that coefficients or standard errors could be biased by spillovers across the network. If such bias existed, we should see large changes when we include neighborhood fixed effects, which we do not observe in Table 1. We would also expect to see large changes when we vary the weight that we place on close vs. distant ties in our centrality measures, which again we do not see in Figure 3. Finally, to mitigate the risk that our standard errors could be biased by errors that are correlated according to the network structure, we presented supplementary standard errors in Table 1 that are clustered by network neighborhood. These are substantively similar to the robust standard errors that we present as our main estimates. Ultimately, although we are able to rule out many plausible sources of endogeneity, these results are not evidence of a causal relationship between centrality and coup participation. 


\section{Elite Benefits of Coup Participation}

In this section we estimate the differential increase in prices that coup participators enjoy during autocracy. This analysis explores a plausible implication of our model that coup participators will enjoy rents from less competitive markets during autocratic regimes. We use a difference-in-difference design that controls for timeinvariant product characteristics and compares changes in prices for coup participants and nonparticipants during periods of autocracy. We also include lagged measures of our dependent variable measuring prices to control for dynamic responses of prices to regime type over time. We estimate variants of the following specification:

$$
\begin{aligned}
\log \left(p_{i t}\right)= & \sum_{k=1}^{4} \rho_{k} \log \left(p_{i t-k}\right)+\text { Coup }_{i} \times \text { Autocracy }_{t} \\
& +X_{i t}^{\prime} \beta+\mu_{t}+\psi_{i}+\varepsilon_{i t}
\end{aligned}
$$

where $p_{\text {it }}$ measures retail prices during period $t$ for product $i$. We control for time-varying common shocks with a time fixed effect $\mu_{t}$, and we also add a product fixed effect $\psi_{i}$ to control for time-invariant product differences. $X_{\text {it }}^{\prime}$ is a vector of time-varying productspecific controls.

All prices are measured as levels in the log price indexed to August 2004. The retail prices used in this analysis are inputs into the consumer price index collected by the Institut Haïtien de Statistiques et Information and cover 18 of the most common products in Haiti. The data on supply prices comes from the US Census Bureau data on international trade between the US and the rest of the world. Coup $i$ is a continuous measure of the proportion of the market for a product that is controlled by families who participated in the 1991 coup and is the empirical analogue of $W^{\prime} a$ from our model, with the caveat that $a$ is unobserved and all we see is the binary variable corresponding to appearance on the OFAC list. All data from families are aggregated to the product level. Appendix Table A4 shows summary statistics for our product-level data.

We estimate this model using OLS with standard errors clustered by product. We have a small number of clusters, and so we report wild bootstrap clustered standard errors in square brackets (Cameron, Gelbach, and Miller 2008). While we have both fixed effects and lagged dependent variables as controls, we also have a long panel of 145 months, so Nickell bias is unlikely to be large (Nickell 1981). Nonetheless Appendix E.1 shows robustness to GMM estimators as well as different assumptions on a fixed autocorrelation parameter in OLS.

Column 1 in Table 2 estimates the effect of the interaction of Coup $_{i} \times$ Autocracy $_{t}$ with product and month fixed effects. We also estimate the differential increase of being a coup participator during the month after the January 2010 earthquake, when government capacity was diminished and markets were disrupted. Column 2 adds one lagged measure of our dependent variable in levels to control for dynamic trends in prices. Column 3 adds three additional lags of the dependent variable. Column 4 adds the world supply price as a control. Column 5 adds the interaction of two other product-specific characteristics (the number of firms per product and our proxy for demand inelasticity) and a dummy for being in an autocratic period. We also include an interaction of the product fixed effects and the number of conflict events in the GDELT data (Leetaru and Schrodt 2013) in order to control for the fact that some products' prices may increase during periods of instability. In Column 6, we add the interaction of centrality and being in an autocratic or postearthquake period. Columns 7 and 8 change the dependent variable to the supply price of each good imported into Haiti and the supply price of each good globally as placebos to check that supply prices of goods being imported are not changing differentially for coup participators.

Columns 1-6 in Table 2 show that retail prices of goods imported by coup participators rise significantly during periods of autocracy. During autocratic periods, a product that is imported only by coup participators grows by about $1.8 \%$ per month faster than products imported by nonparticipants. ${ }^{7}$ Accounting for the price dynamics, this translates to a $33 \%$ increase in the price of the good over the long term. Substantively, this means that moving from the sample mean of $60 \%$ coup participation by one standard deviation to $80 \%$ is associated with a $0.51 \%$ increase in short-run prices, increasing to $6.3 \%$ taking price dynamics into account. Taking as our benchmark product rice, which cost on average 0.25 USD per pound at contemporary exchange rates in the precoup period, and a coup participation rate of $88 \%$, our estimates imply that the transition to dictatorship increased the price of rice by $34 \%$. Given that many of the other staple goods like corn meal, sugar, and chicken also have high levels of coup participation, price increases of this magnitude would have had a large effect on the budget of an average household.

There is no evidence that the supply price of goods imported into Haiti or of goods globally is changing differentially for coup participators during autocratic periods. Adding the global supply price as a control variable in Columns 3-6 does not change the coefficient on coup participation interacted with autocracy. Appendix Table A13 shows this relationship is robust to including time-variant measures of product characteristics.

To visualize these effects, Figure 4 presents a flexible estimation of the relationship between coup participation by product and time. The estimates plotted in Figure 4 are in line with expectations: after the 2004 coup we see a differential spike in the prices of products imported by coup participants. These coup benefits generally rise during the period of autocracy. At the

\footnotetext{
${ }^{7}$ The interaction is positively and significantly associated with prices, conditional on Coup $\times$ Autocracy. One interpretation of this result is that our binary measure of coup participation is not picking up the full variation of contributions to the coup that are rewarded by the dictator.
} 


\section{TABLE 2. Prices of Goods Imported by Coup Participators during Autocratic Periods}

\begin{tabular}{|c|c|c|c|c|c|c|c|c|}
\hline & \multicolumn{7}{|c|}{ Dependent variable: } & \multirow{3}{*}{$\begin{array}{c}\text { World supply price } \\
\text { (8) }\end{array}$} \\
\hline & \multicolumn{6}{|c|}{ Haiti retail price } & \multirow{2}{*}{$\begin{array}{c}\text { Haiti supply price } \\
(7)\end{array}$} & \\
\hline & $(1)$ & $(2)$ & (3) & $(4)$ & $(5)$ & (6) & & \\
\hline Coup $\times$ autocracy & $\begin{array}{l}0.188^{\star \star} \\
(0.073) \\
{[0.067]}\end{array}$ & $\begin{array}{c}0.022^{\star \star \star} \\
(0.006) \\
{[0.006]}\end{array}$ & $\begin{array}{c}0.021^{\star \star *} \\
(0.005) \\
{[0.005]}\end{array}$ & $\begin{array}{c}0.021^{\star * *} \\
(0.006) \\
{[0.005]}\end{array}$ & $\begin{array}{l}0.018^{\star *} \\
(0.007) \\
{[0.006]}\end{array}$ & $\begin{array}{c}0.023^{\star \star \star} \\
(0.008) \\
{[0.007]}\end{array}$ & $\begin{array}{c}0.190 \\
(0.332) \\
{[0.314]}\end{array}$ & $\begin{array}{c}0.066 \\
(0.066) \\
{[0.063]}\end{array}$ \\
\hline Coup $\times$ quake & $\begin{array}{c}0.102 \\
(0.150)\end{array}$ & $\begin{array}{l}0.074 \\
(0.047)\end{array}$ & $\begin{array}{c}0.072 \\
(0.047)\end{array}$ & $\begin{array}{l}0.072 \\
(0.047)\end{array}$ & $\begin{array}{l}0.069^{\star} \\
(0.041)\end{array}$ & $\begin{array}{l}0.069 \\
(0.045)\end{array}$ & $\begin{array}{c}0.717^{\star \star \star} \\
(0.270)\end{array}$ & $\begin{array}{l}-0.218 \\
(0.157)\end{array}$ \\
\hline Centrality $\times$ autocracy & & & & & & $\begin{array}{l}0.001^{* *} \\
(0.0003)\end{array}$ & & \\
\hline Centrality $\times$ quake & & & & & & $\begin{array}{l}0.00005 \\
(0.002)\end{array}$ & & \\
\hline World supply price & & & & $\begin{array}{c}0.001 \\
(0.004)\end{array}$ & $\begin{array}{c}-0.0003 \\
(0.004)\end{array}$ & $\begin{array}{l}-0.0003 \\
(0.004)\end{array}$ & & \\
\hline Number firms $\times$ autocracy & & & & & $\begin{array}{l}-0.003 \\
(0.002)\end{array}$ & $\begin{array}{l}-0.002 \\
(0.002)\end{array}$ & & \\
\hline Consumption share $\times$ autocracy & & & & & $\begin{array}{c}-0.0005 \\
(0.001)\end{array}$ & $\begin{array}{l}-0.0004 \\
(0.0005)\end{array}$ & & \\
\hline Month FE & $\checkmark$ & $\checkmark$ & $\checkmark$ & $\checkmark$ & $\checkmark$ & $\checkmark$ & $\checkmark$ & $\checkmark$ \\
\hline Product FE & $\checkmark$ & $\checkmark$ & $\checkmark$ & $\checkmark$ & $\checkmark$ & $\checkmark$ & $\checkmark$ & $\checkmark$ \\
\hline Number of lagged DVs & & 1 & 4 & 4 & 4 & 4 & 4 & 4 \\
\hline Product $\times$ conflict events & & & & $\checkmark$ & $\checkmark$ & & & \\
\hline Observations & 2,538 & 2,448 & 2,250 & 2,214 & 2,214 & 2,214 & 1,938 & 2,304 \\
\hline Clusters & 18 & 18 & 18 & 18 & 18 & 18 & 18 & 18 \\
\hline Breusch-Godfrey test ( $p$-value) & $<0.001$ & $<0.001$ & 0.82 & 0.86 & 0.7 & 0.666 & 0.159 & $<0.001$ \\
\hline Joint signif. of lags ( $p$-value) & & $<0.001$ & $<0.001$ & $<0.001$ & $<0.001$ & $<0.001$ & $<0.001$ & $<0.001$ \\
\hline Unit root ( $p$-value) & & $<0.001$ & $<0.001$ & $<0.001$ & $<0.001$ & $<0.001$ & $<0.001$ & $<0.001$ \\
\hline
\end{tabular}


FIGURE 4. Coefficients on Interactions between Month and Coup Participation

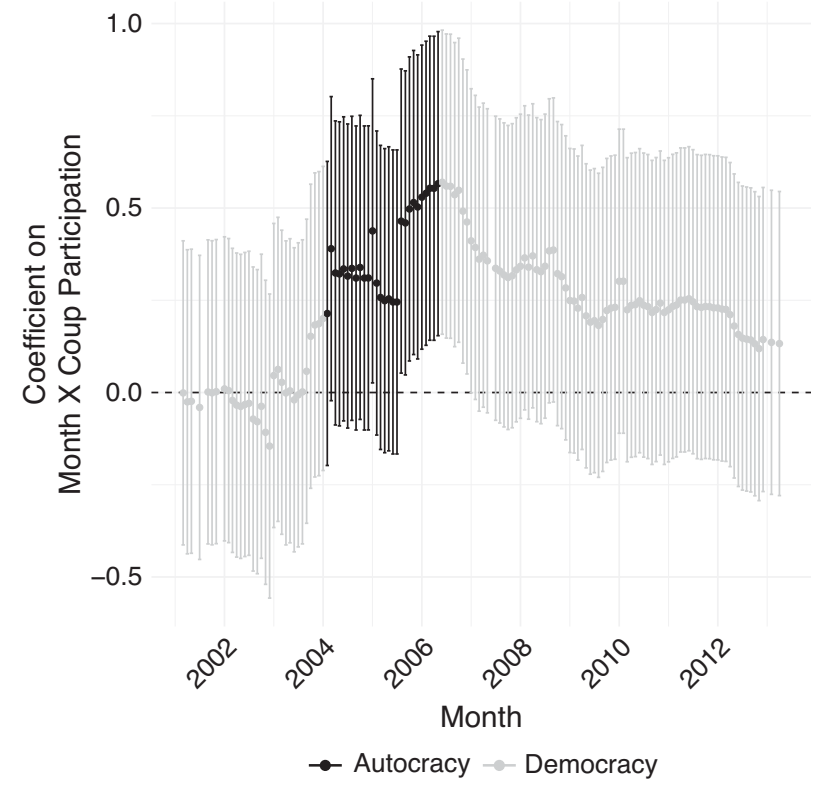

Note: This figure shows the coefficient on product-level coup participation on price for each month, with autocratic months shaded black

moment that René Préval takes office in June 2006, they begin to decline.

Appendix E presents additional robustness checks, including tests and additional specifications to deal with serial correlation, inclusion of additional product-level controls, analyses that take into account potential variation in data quality, a placebo test that moves the window of autocracy, and an analysis that validates that the results are not being driven by a single product.

\section{CONCLUSION}

In this article we have developed and empirically explored a theory of the role of elite social networks in coups against democracy. We developed a model of coups based on actions taken by elites that are directed at putting a dictator in power. The most important result is that the amount of effort that an elite member puts into organizing a coup is positively related to his network centrality. Moreover, this implies that the higher an elite agent's centrality, the higher the probability that he will appear on a unique US sanctions list for taking part in the coup. Further, the sectors owned by coup participants are more likely to experience differential price increases during autocracy.

To test the model we constructed a unique dataset of Haitian elites. We found that elite family centrality is positively correlated with coup participation, and this result is robust to a variety of specifications. We also found that prices of goods produced by firms disproportionately owned by coup participants differentially increased after the transition to autocracy. Together, this evidence points toward elite social structure as an important factor that works in conjunction with elite economic interests to explain the persistence of predatory, autocratic institutions. This adds to our understanding of elite de facto power as shaped by not only economic but also social characteristics.

To what extent should this theory generalize? There are many unique aspects of the Haitian case, but our results imply that it is the high relative network centralities of Haiti's economic elite that have made it particularly susceptible to coups, suggesting that we should see similar outcomes in other countries with tightly networked elites. While rich data on elite networks is rare, there is a sociological literature on "assortative mating," or marriages between individuals with similar characteristics, which could create a tightly networked elite. Indeed, some of the Latin American countries with the highest levels of assortative mating such as Venezuela and Argentina have also had the most coups, while some of those with the lowest levels of assortative mating such as Brazil and Costa Rica have had very few (Ganguli, Hausmann, and Viarengo 2014; Powell and Thyne 2011).

More broadly, our results have implications for democratization and democratic consolidation. While previous theories have focused on reforming institutions or redistributing assets as mechanisms for consolidating democracy, our results suggest that transforming elite networks during democracy may be an important component of reducing the likelihood of future coups. Indeed, elite social capital may have to decay for democratic capital to accumulate. Stepping back from Haiti, our results suggest that it is not only the interest of elites in preserving autocracy but also their ability to effectively fight democracy, as shaped by the density of elite social networks, that may explain the incidence of coups and whether or not democracy consolidates. In 
line with this Berman (2019) concludes that democratic consolidation "requires transforming not merely the political procedures and institutions of dictatorship, but societies and economies as well" (386). Our results are very consistent with her emphasis.

\section{SUPPLEMENTARY MATERIALS}

To view supplementary material for this article, please visit http://dx.doi.org/10.1017/S0003055421000289.

\section{DATA AVAILABILITY STATEMENT}

Replication files are available at the American Political Science Review Dataverse: https://doi.org/10.7910/ DVN/IM0FZN.

\section{ACKNOWLEGMENTS}

We thank PEDL, INURED, the Columbia Population Research Centre, and the Harvard Weatherhead Program for research support. We thank Louis Marcelin, Paul Farmer, and the late Patrick Elie for valuable contacts and conversations about Haiti. Becky Simonson, Jeff Jacobs, and Ellora Derenoncourt all provided valuable research assistance.

\section{REFERENCES}

Acemoglu, Daron, Davide Ticchi, and Andrea Vindigni. 2010. "A Theory of Military Dictatorships.” American Economic Journal: Macroeconomics 2 (1): 1-42.

Acemoglu, Daron, and James A. Robinson. 2001. "A Theory of Political Transitions.” American Economic Review 91 (4): 938-63. Acemoglu, Daron, and James A. Robinson. 2006. Economic Origins of Dictatorship and Democracy. Cambridge: Cambridge University Press.

Acemoglu, Daron, and James A. Robinson. 2008. "Persistence of Power, Elites and Institutions." American Economic Review 98 (1): 267-93.

Acemoglu, Daron, Suresh Naidu, Pascual Restrepo, and James A Robinson. 2019. "Democracy Does Cause Growth." Journal of Political Economy 127 (1): 47-100.

Altonji, Joseph G., Todd E. Elder, and Christopher R. Taber. 2005. "Selection on Observed and Unobserved Variables: Assessing the Effectiveness of Catholic Schools." Journal of Political Economy 113 (1): 151-84.

Anderson, Siwan, Patrick Francois, and Ashok Kotwal. 2015. "Clientelism in Indian villages." American Economic Review 105 (6): $1780-816$.

Arthur, Charles. 2005. "2005 World Press Freedom Review-Haiti, International Press Institute.” Technical Report. Institute for Justice and Democracy in Haiti. http://www.ijdh.org/2006/03/ archive/2005-world-press-freedom-review-haiti-internationalpress-institute/.

Bailey, Michael, Rachel Cao, Theresa Kuchler, Johannes Stroebel, and Arlene Wong. 2018. "Social Connectedness: Measurement, Determinants, and Effects." Journal of Economic Perspectives 32 (3): 259-80.

Ballester, Coralio, Antoni Calvó-Armengol, and Yves Zenou. 2006. "Who's Who in Networks. Wanted: The Key Player." Econometrica 74 (5): 1403-17.

Berman, Sheri. 2019. Democracy and Dictatorship in Europe: From the Ancien Régime to the Present Day. Oxford: Oxford University Press.
Bonacich, Phillip. 1987. "Power and Centrality: A Family of Measures.” American Journal of Sociology 92 (5): 1170-82.

Cameron, A. Colin, Jonah B. Gelbach, and Douglas L. Miller. 2008. "Bootstrap-based Improvements for Inference with Clustered Errors." The Review of Economics and Statistics 90 (3): 414-27.

Carter, Brett L. 2014. Inside Autocracy: Political Survival and the Modern Prince. PhD. diss. Harvard University. http:// nrs.harvard.edu/urn-3:HUL.InstRepos:13065026.

Clauset, Aaron, Mark E. J. Newman, and Cristopher Moore. 2004. "Finding Community Structure in Very Large Networks." Physical Review E 70 (6): 066111.

Cruz, Cesi, Julien Labonne, and Pablo Querubin. 2017. "Politician Family Networks and Electoral Outcomes: Evidence from the Philippines.” American Economic Review 107 (10): 3006-37.

Dasgupta, Aditya, and Daniel Ziblatt. 2014. "How did Britain Democratize? Views from the Sovereign Bond Market." Journal of Economic History 75 (1): 1-29.

de la Sierra, Raul Sanchez. 2020. "On the Origin of States: Stationary Bandits and Taxation in Eastern Congo." Journal of Political Economy 128 (1): 32-74.

Diani, Mario, and Doug McAdam. 2003. Social Movements and Networks. Relational Approaches to Collective Action. New York: Oxford University Press.

Dube, Arin, Ethan Kaplan, and Suresh Naidu. 2011. "Coups, Corporations, and Classified Information." Quarterly Journal of Economics 126 (3): 1375-409.

Dupuy, Alex. 2007. The Prophet and Power: Jean-Bertrand Aristide, the International Community, and Haiti. New York: Rowman \& Littlefield Publisher.

Farmer, Paul. 1994. The Uses of Haiti. Austin, TX: Common Courage Press.

Fass, Simon M. 1988. Political Economy in Haiti: The Drama of Survival. New Brunswick, NJ: Transaction Publishers.

Fatton, Robert. 2002. Haiti's Predatory Republic: The Unending Transition to Democracy. Boulder, CO: Lynne Rienner.

French, Howard. 1991. "Haiti Police Seen as Gaining in Coup." The New York Times, October 13. http://www.nytimes.com/1991/10/13/ world/haiti-police-seen-as-gaining-in-coup.html.

Galeotti, Andrea, Sanjeev Goyal, Matthew O. Jackson, Fernando Vega-Redondo, and Leeat Yariv. 2010. "Network Games." Review of Economic Studies 77 (1): 218-44.

Ganguli, Ina, Ricardo Hausmann, and Martina Viarengo. 2014. "Marriage, Education and Assortative Mating in Latin America." Applied Economics Letters 21 (12): 806-11.

García-Jimeno, Camilo, Angel Iglesias, and Pinar Yildirim. 2018. Women, Rails and Telegraphs: An Empirical Study of Information Diffusion and Collective Action. Technical Report. National Bureau of Economic Research.

Hallward, Peter. 2007. Damming the Flood: Haiti, Aristide, and the Politics of Containment. London: Verso Books.

Hausmann, Ricardo, César A. Hidalgo, Sebastián Bustos, Michele Coscia, Sarah Chung, Juan Jimenez, Alexander Simoes et al. 2013. The Atlas of Economic Complexity: Mapping Paths to Prosperity. Cambridge, MA: MIT Press.

Henrich, Natalie, and Joseph Patrick Henrich. 2007. Why Humans Cooperate: A Cultural and Evolutionary Explanation. Oxford: Oxford University Press.

Hummels, David. 2007. "Transportation Costs and International Trade in the Second Era of Globalization." Journal of Economic Perspectives 21 (3): 131-54.

Jackson, Matthew O. 2008. Social and Economic Networks. Princeton, NJ: Princeton University Press.

Jensen, Helen H., Stanley R. Johnson, and Gary L. Stampley. 1990. "Nutrition in Haiti: Evidence from the Haiti Household Expenditure and Consumption Survey." Staff Report 90-SR 52. Center for Agricultural and Rural Development, Iowa State University.

Jones, J. Bascom. 1919. Haiti 1919-1920: Blue Book of Hayti. New York: Klebold Press.

König, Michael D., Dominic Rohner, Mathias Thoenig, and Fabrizio Zilibotti. 2017. "Networks in Conflict: Theory and Evidence from the Great War of Africa." Econometrica 85 (4): 1093-132.

Leetaru, Kalev, and Philip A. Schrodt. 2013. "GDELT: Global Data on Events, Location, and Tone." Paper presented at the International Studies Association Annual Convention, San Francisco, April 3-6. 
Lundahl, Mats. 1979. Peasants and Poverty: A Study of Haiti. New York: St Martin's Press.

McCarthy, John D., and Mayer N. Zald. 1977. "Resource Mobilization and Social Movements: A Partial Theory." American Journal of Sociology 82 (6): 1212-41.

Mitra, Devashish, Dimitrios D. Thomakos, and Mehmet A. Ulubaşŏglu. 2002. "Protection for Sale in a Developing Country: Democracy vs. Dictatorship." Review of Economics and Statistics 84 (3): 497-508.

Naidu, Suresh. 2012. "Suffrage, Schooling, and Sorting in the PostBellum U.S. South.” NBER Working Paper 18129.

Nickell, Stephen. 1981. "Biases in Dynamic Models with Fixed Effects." Econometrica 49 (6): 1417-26.

O'Donnell, Guillermo, and Philippe C. Schmitter. 1986. Transitions from Authoritarian Rule: Tentative Conclusions about Uncertain Democracies. Washington, DC: Johns Hopkins Press.

Offe, Claus, and Helmut Wiesenthal. 1980. "Two Logics of Collective Action: Theoretical Notes on Social Class and Organizational Form." Political Power and Social Theory 1 (1): 67-115.

Oster, Emily. 2019. "Unobservable Selection and Coefficient Stability: Theory and Evidence." Journal of Business \& Economic Statistics 37 (2): 187-204.

Padgett, John F., and Chrsitopher K. Ansell. 1993. "Robust Action and the Rise of the Medici, 1400-34." American Journal of Sociology 98 (6): 1259-319.

Plummer, Brenda Gayle. 1988. Haiti and the Great Powers, 1902-1915. Baton Rouge: Lousiana State University Press.
Podur, Justin. 2013. Haiti's New Dictatorship: The Coup, The Earthquake and the UN Occupation. London: Pluto Press.

Powell, Jonathan M., and Clayton L. Thyne. 2011. "Global Instances of Coups from 1950 to 2010: A New Dataset." Journal of Peace Research 48 (2): 249-59.

Puga, Diego, and Daniel Trefler. 2014. "International Trade and Institutional Change: Medieval Venice's Response to Globalization.” Quarterly Journal of Economics 129 (2): 753-821. Rauch, James E. 1999. "Networks versus Markets in International Trade." Journal of International Economics 48 (1): 7-35.

Rotberg, Robert I. 1971. Haiti: The Politics of Squalor. Boston: Houghton Mifflin Company.

Schuller, Mark. 2008. "Behind Haiti's Food Riots." International Socialist Review 59. https://isreview.org/issues/59/rep-haiti.shtml.

Sprague-Silgado, Jeb. 2018. "Global Capitalism, Haiti, and the Flexibilisation of Paramilitarism." Third World Quarterly 39 (4): $747-68$.

Supplice, Daniel. 2001. Dictionnaire biographique des personnalités politiques de la République d'Haïti. Belgium: Imprimerie Lannoo. Supplice, Daniel. 2009. De La Naturalisation en Haiti. Port-au-Prince: Imprimerie Henri Deschamps.

Weiner, Tim. 2004. "The Price of Rice Soars, and Haiti's Hunger Deepens." The New York Times, June 1. http://www.nytimes.com/ 2004/06/01/world/the-price-of-rice-soars-and-haiti-s-hungerdeepens.html.

Zald, Mayer N., and John D. McCarthy. 1987. Social Movements in an Organizational Society. New Brunswick, NJ: Transaction Books. 